COSTA, AC; COELHO, FC; GARCIA, RV; LIMA, WL; VIVAS, M; PRINS, CL; ROCHA, JG. 2020. Performance of maize seedlings for baby corn production. Horticultura Brasileira 38: 421-427. DOI: http://dx.doi.org/10.1590/s0102-0536202004013

\title{
Performance of maize seedlings for baby corn production
}

\section{Ariane C Costa ${ }^{1} \mathbb{D}$; Fábio C Coelho ${ }^{1} \mathbb{D}$; Romário V Garcia ${ }^{1} \mathbb{D}$; Wallace Luís de Lima ${ }^{2} \mathbb{D}$; Marcelo Vivas ${ }^{1} \mathbb{D}$; Cláudia L Prins ${ }^{1} \mathbb{D}$; Jaídson $G$ da Rocha ${ }^{1 \mathbb{D}}$}

${ }^{1}$ Universidade Estadual do Norte Fluminense (UENF), Campos dos Goytacazes-RJ, Brasil; arianecardosocosta@hotmail.com; fabiocoelhouenf@gmail.com; romariovg9@gmail.com; mrclvivas@hotmail.com; prins@uenf.br; jaidsongr@yahoo.com.br. ${ }^{2}$ Instituto Federal do Espirito Santo (IFES), Alegre-ES, Brasil; wallace@ifes.edu.br

\begin{abstract}
Using maize seedlings for baby corn production can benefit farmers who have small areas under cultivation. The objective of this study was to evaluate the possibility of using maize seedlings for the production of baby corn. The experiment was carried out in field with four treatments (direct sowing in field; transplanting seedlings 10 days after sowing (DAS); 20 DAS and 30 DAS) in randomized blocks with eight replications. Plants from seedlings 30 DAS were higher than sowing direct in field. Direct sowing in field and seedlings 30 DAS resulted in the largest stands. Sowing direct in field and transplanting seedlings at 20 and 10 DAS presented the highest number of total and commercial ears, while crops obtained from direct sowing in field yielded higher compared to the crops in which seedlings were used. Crops from maize seedlings transplanted at 10,20 and 30 DAS reduced the period of maize plants in field by 14, 22 and 28 days, respectively, compared to maize sown directly in field. However, baby corn from direct sowing yielded $37 \%$ more than those in which seedlings were used. We concluded that the use of maize seedlings caused reduction in baby corn productivity however, it presents the advantage of reducing the permanence of the maize plants in field.
\end{abstract}

Keywords: Zea mays, phenology, seedling production.

\section{RESUMO}

Desempenho de mudas de milho para produção de minimilho

A utilização de mudas de milho para produção de minimilho pode beneficiar agricultores que têm pequenas áreas de cultivo. Objetivou-se avaliar a possibilidade de utilização de mudas de milho para a produção de minimilho. O experimento foi realizado no campo com quatro tratamentos (semeadura direta no campo; transplantio de mudas aos 10 dias após a semeadura (DAS); transplantio aos 20 DAS e transplantio aos 30 DAS). Utilizaram-se blocos casualizados com oito repetições. As plantas de milho de mudas 30 DAS apresentaramse mais altas que as provenientes de semeadura direta. A semeadura direta no campo e mudas de 30 DAS resultaram nos maiores estandes. A semeadura direta no campo e os transplantios de mudas aos 20 e 10 DAS apresentaram os maiores números de espigas totais e comerciais. A utilização de mudas de milho com 10, 20 e 30 DAS reduziram o período das plantas no campo em 14, 22 e 28 dias, respectivamente, em comparação com o milho semeado diretamente no campo. No entanto, a semeadura direta resultou em produtividade $37 \%$ maior em comparação ao uso de mudas. Concluiu-se que a utilização de mudas para a produção de minimilho causa redução na produtividade, porém, resulta em redução da permanência das plantas de milho no campo.

Palavras chave: Zea mays, fenologia, produção de mudas.

Received on May 25, 2020; accepted on August 7, 2020

$\mathrm{T}$ he use of small areas for vegetable production is increasing in the world. That occurs both in urban and peri-urban agriculture and is usually carried out by family farmers. In this way, agricultural techniques that allow shorter land use are very important. One way to reduce the land use period is to use seedlings, so less land is used in field in the initial stages of the plants. Thus, plants in initial phase can grow outside the main agriculture area and after transplanting they remain for a shorter period in field until harvest.

Usually, maize plants are sown directly in field and this technique is ancient. In this way, nobody uses to produce seedlings in the maize cropping, mainly because it is grown in large areas. On the other hand, the production of baby corn can be carried out in vegetable gardens in small areas. However, there is no information about the use of maize seedlings for the baby corn production. Thus, the working hypothesis is that the use of maize seedlings reduces the period of land use to produce baby corn.

The cultivation of baby corn is one of the alternatives found to diversify production and increase profitability in family agriculture in urban and periurban areas. Baby corn production yields gains four to five times that of grain maize (Thakur et al., 1998). In addition, the production of organic baby corn has attracted more and more consumers and producers due to advantages in terms of greater sustainability and profitability (Lima et al., 2015). Thus, Araújo et al. (2010) argue that the baby corn culture is a viable alternative to increase the income of the producer, because, in addition to the main product (baby corn), the farmer still has the by-product, which consists of the maize plant, which can be used in animal food.

Baby corn cultivation can be compared to that of vegetable crops because the sowing period until harvest is short, on average 60 days. In summer, it can be harvested in up to 45 days, depending on the precocity and the cultivar used. Even in winter months, 
in tropical regions, even using early cultivars, this period can reach 70 days (EMBRAPA, 2008).

The basis of modern horticulture is the production of high quality seedlings. The implantation of crops with well-formed seedlings is essential for maximizing the genetic potential of a species (Nascimento \& Pereira, 2016). Thus, the production of seedlings is one of the most important stages of the horticultural production system. It depends on the final performance of the plants at the sites of production, both from the nutritional point of view and the period required for production and, consequently, the number of productive cycles per year (Carmello, 1995). For these reasons, nurseries producing seedlings have improved in this activity (Madeira et al., 2016).

The use of maize seedlings for baby corn production may benefit mainly Brazilian family producers, because they have small areas for their crops. These farmers, using seedlings, could plan and obtain more baby corn plantings per year, so their net income would possibly increase, benefiting the gains from crop exploitation. In addition, Salata et al. (2011) report that the use of seedlings reduces the achievement of initial cultural practices (thinning, weeding, irrigation and spraying), and provides greater homogeneity among plants. In addition, it reduces the time of the plant in field, reducing its exposure to pests and diseases. On the other hand, the possibility of producing maize seedlings associated to microorganisms that decrease the dependence of chemical fertilizers is a future possibility as reported by Yadava et al. (2018).

The aim of this work was to evaluate the use of maize seedlings in the baby corn prodution, checking about the possibility to reduce the period of land use in field and if the productivity is similar to that of maize sown directly in field.

\section{MATERIAL AND METHODS}

The experiment was carried out between September 2016 and April 2017, in the Alegre town, Espírito Santo state, Brazil $\left(20^{\circ} 45^{\prime} \mathrm{S}, 4^{\circ} 27^{\prime} \mathrm{W}, 108 \mathrm{~m}\right.$ altitude). According to the international classification of Köppen, the climate of the region is Cwa (tropical hot humid), with cold and dry winter and hot and rainy summer. The average annual rainfall is $1,341 \mathrm{~mm}$ (Lima et al., 2008) and $23.1^{\circ} \mathrm{C}$ the average temperature. The soil of the site is classified as Typic Hapludox, being characterized: $\mathrm{pH}=$ 5.9; Soil organic matter $(\mathrm{SOM})=2.3$ dag $\mathrm{dm}^{-3}, \mathrm{P}, \mathrm{K}, \mathrm{B}, \mathrm{Zn}, \mathrm{Mn}, \mathrm{Cu}, \mathrm{Fe}$ and $\mathrm{S}=78.5 ; 256 ; 10.74 ; 4.0 ; 92 ; 1.3 ; 41$ and $33 \mathrm{mg} \mathrm{dm}^{-3}$, respectively and $\mathrm{Ca}$, $\mathrm{Mg}, \mathrm{Al}, \mathrm{H}+\mathrm{Al}$, sum of bases (SBs) and cation exchange capacity $(\mathrm{CEC})=4.2$; $1.2 ; 0 ; 2.8 ; 6.12$ and $8.68 \mathrm{cmol}_{\mathrm{c}} \mathrm{dm}^{-3}$, respectively.

The experiment was carried out from the maize seedlings production, afterwards by planting it in field followed by evaluations of plant characteristics and, finally, by evaluations of young ears production for baby corn production.

The treatments in field were composed of: 1) maize seeding direct in field (conventional); 2) transplanting at 10 DAS (days after sowing) maize seedlings in stage V1;3) transplanting of maize seedlings at 20 DAS in V2 stage; 4) transplanting of maize seedlings at 30 DAS in V3 stage. The experimental design was randomized complete blocks with 4 treatments and eight replicates, totaling 32 experimental units.

In field, each experimental unit consisted of a plot of $3.2 \mathrm{~m} \times 1.0 \mathrm{~m}$, in which it contained four lines $1 \mathrm{~m}$ in length, spaced at $0.80 \mathrm{~m}$. During the evaluation of the experiment the two central lines were used, thus, the harvest area was $1.6 \mathrm{~m}^{2}$.

Maize seedlings of cultivar 'UENF 14' were produced in the experimental first stage, from September to November 2016. We evaluated the period for each treatment to reach the desired phenological stages. Phenological stages were characterized by the number of totally expanded leaves in the maize plant: seedlings with one fully expanded leaf, stage V1 (treatment 2), seedlings with two fully expanded leaves, stage V2 (treatment 3 ) and seedlings with three fully expanded leaves, V3 (treatment 4) (Figure 1).

The production of maize seedlings started in December 2016. One maize seed per pot was sown at $2 \mathrm{~cm}$ depth. The containers consisted of polyethylene cups, $200 \mathrm{~mL}$ volume, $8.41 \mathrm{~cm}$ height and $7.04 \mathrm{~cm}$ diameter, with four holes ( $2 \mathrm{~mm}$ diameter) in the lower part. The cups were completed with soil and broiler litter, in 1:1 proportion. The soil and broiler litter were sieved in sieves with a $4 \mathrm{~mm}$ opening mesh. After sowing, the containers were taken to a ventilated place, with cement floor, under $35 \%$ shading. This shaded environment is the one normally used by urban and peri-urban farmers in the production of vegetable seedlings in the region where the experiment was carried out.

Irrigation using mobile micro sprinklers was performed twice a day (at 7:00 a.m. and 4:00 p.m.) until reaching the waterholding capacity. The treatment 4 was seeded 10 days before treatment 3 , which in turn was seeded 10 days before treatment 2 which in turn was seeded 10 days before transplanting in field. Thus, the seedlings were obtained in stages V3, V2 and V1 to be transplanted in field simultaneously on the same day, with 30, 20 and 10 DAS, respectively.

In January 2017, in field, the soil preparation was carried out by plowing and harrowing. Soon after, organic fertilization was carried out with broiler litter in the proportion of $6 \mathrm{t} \mathrm{ha}^{-1}$ (Pereira Júnior et al., 2012). The broiler litter was characterized and contained $21 ; 8.8$; $14 ; 116.6 ; 6.7$ and $4.3 \mathrm{~g} \mathrm{~kg}^{-1}$ of $\mathrm{N} ; \mathrm{P} ; \mathrm{K}$; $\mathrm{Ca}$; $\mathrm{Mg}$ and $\mathrm{S}$, respectively and 18.61 ; $213.35 ; 366.5 ; 725$ and $69.1 \mathrm{mg} \mathrm{kg}^{-1} \mathrm{~B}$; $\mathrm{Zn}$; $\mathrm{Mn} ; \mathrm{Fe}$ and $\mathrm{Cu}$, respectively. This organic fertilizer was distributed in the grooves, being mixed to the soil.

The experiment was installed in field, 15 days after the organic fertilization, when 24 maize seeds per linear meter on groove were sown, corresponding to treatment 1 (maize sown directly in field, conventional treatment) and transplanted 14 seedlings per linear meter for the others treatments in V1, $\mathrm{V} 2$ and V3 stages.

Seed emergence occurred on the $5^{\text {th }}$ day after sowing in treatment 1 . On the $15^{\text {th }}$ day the treatment 1 was thinned to reach the population of 14 plants 
$\mathrm{m}^{-1}$ groove, resulting in a population of 175,000 plants ha ${ }^{-1}$ (Bastiani et al., 2012). During the thinning, organic fertilization with $6 \mathrm{t} \mathrm{ha}^{-1}$ of broiler litter was carried out, which was distributed in lines adjacent to the maize plants of all treatments.

For fall armyworm (Spodoptera frugiperda) control leaf sprays were used with biological insecticide Dipel $\mathrm{WP}{ }^{\circledR}$, based on Bacillus thuringiensis $\left(500 \mathrm{~g} \mathrm{ha}^{-1}\right)$. Weeds were controlled manually with a hoe, on the $25^{\text {th }}$ day after transplanting or sowing.

Plant height (PLH), plant stem diameter (PSD), final plant stand of maize (STA) and number of days for baby corn production were evaluated. In order to determine PLH, five central plants of the harvest area of each treatment were evaluated, after emergence of the first cob and height was determined between the distance of the soil level and the leaf sheath of the last leaf. To determine the PSD, five central plants of the harvest area were evaluated after emergence of the first cob. A digital caliper calibrated in millimeters was used. For measurement, the beginning of the first training from the soil surface of each plant was considered. For determination of STA, all survived plants of the harvest area of each experimental unit were counted. This count was performed in the fourth week after the beginning of the corn cob harvest.

Thus, the number of days of seedling preparation (container) until the transplanting, emission of the first ear and harvest period were quantified. The harvest begun when the first ear silk appeared (Kara \& Bozkurt, 2018). To verify the number of days until the end of the harvest, in each treatment, each production stage was counted.

Three harvests per week were carried out over four weeks, totaling twelve harvests per treatment. The harvests were carried out between 07:00 and 09:00 a.m. After each harvest, the ears were conditioned in a cold chamber at temperatures ranging from 5 to $12^{\circ} \mathrm{C}$ until the determinations.

To evaluate the total number ears (NTE), all ears present in the harvest area of each experimental unit were counted. For commercial ears (NCE) the standard for commercial ears was used, according to Pereira Filho \& Cruz (2001), being 4 to $12 \mathrm{~cm}$ in length and 1.0 to $1.8 \mathrm{~cm}$ in diameter per ear. The productivity was obtained from the weight of the total (WTE) and commercial ears (WCE) of the harvested area, by weighing in a precision balance being expressed in kg per hectare.

For the variables of the maize characteristics in field and production of baby corn, a statistical analysis was performed, and analysis of variance was performed at $5 \%$ probability level. In case of significant effect, the mean comparisons were conducted using the Tukey's test at 5\% probability level. The analysis was performed through the GENES Program (Cruz, 2013).

\section{RESULTS AND DISCUSSION}

The characteristics plant length (PLH) and stem diameter (PSD) gave an idea of the morphological condition of corn plants. The final stand (STA) characterized plant mortality after transplanting. The number of days in field for baby corn production demonstrated how many days the area in field was used. On the other hand, the number of total ears (NTE), number of commercial ears (NCE), weight of the total ears (WTE) and weight of commercial ears (WCE) made it possible to compare the yield of baby corn in direct sowing with that from maize seedlings transplanted.

When the first cob emerged, maize plants transplanted after 30 DAS seedlings were $48.0 \mathrm{~cm}$ taller than maize seeded direct in field and maize transplanted after 10 and 20 DAS presented plants with intermediate lengths (Table 1).

The differences in PLH between treatments possibly occurred due to the low luminosity in the formation of the seedlings. We verified that maize plants of seedlings transplanted on a later date, presented longer plant height (Table 1). This may have occurred

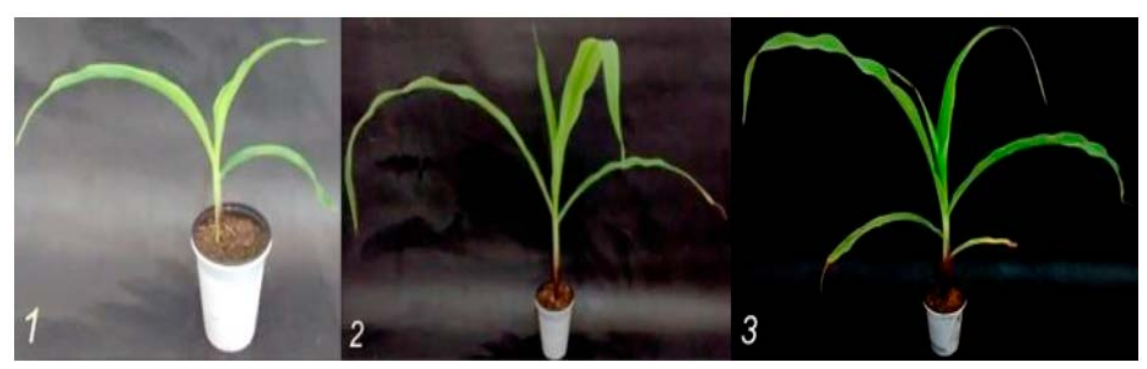

Figure 1. Phenological stages of maize seedlings. $1=$ seedlings with 10 DAS (days after sowing), with a fully expanded leaf(V1);2 = seedlings with 20 DAS, with two fully expanded leaves (V2); 3 = seedlings with 30 DAS, with three fully expanded leaves (V3). Alegre/ Campos dos Goytacazes, IFES/UENF, 2017.

Table 1. Maize plant's height (PLH) and stem diameter (PSD) after direct sowing and seedlings with different DAS (days after sowing) of maize 'UENF 14', after planting in field, for baby corn production, in organic system. Alegre/Campos dos Goytacazes, IFES/ UENF, 2017.

\begin{tabular}{|c|c|c|}
\hline Treatments & PLH (cm) & PSD (mm) \\
\hline Direct sowing & $84.5 \quad \mathrm{~B}$ & $15.2 \mathrm{AB}$ \\
\hline Seedlings with $10 \mathrm{DAS}^{1}$ & $118.6 \mathrm{AB}$ & $16.6 \mathrm{~A}$ \\
\hline Seedlings with 20 DAS & $104.4 \mathrm{AB}$ & $11.7 \mathrm{~B}$ \\
\hline Seedlings with 30 DAS & $132.5 \mathrm{~A}$ & $15.6 \mathrm{AB}$ \\
\hline Means & 110.0 & 14.8 \\
\hline CV (\%) & 29.6 & 20.9 \\
\hline
\end{tabular}

${ }^{1}$ Days after sowing; Means followed by the same letters in the same column do not differ by Tukey test at a $5 \%$ probability level. $\mathrm{CV}=$ coefficient of variation. 
due to the estiolation in the seedlings initial formation, resulting from the lower incidence of light due to the shading used in seedlings production (Figure 1). Thus, comparing the PLH of the plants seeded direct in field with the transplanted seedlings, it is noticed that they were smaller (Table 1), certainly, because they have been exposed to greater luminosity since the initial growth stages. The shaded environment normally used by urban and peri-urban farmers (35\% shading) in the seedlings of vegetable production possibly is not the best for producing maize seedlings. It is important to consider that different levels of clarity or shading in the production of baby corn seedlings should be researched in the future. On average, maize plants presented low stature (Table 1). It is important to point out that low plants for baby corn production are favorable to manual harvesting, which is usually carried out several times per week. In a study performed in climatic conditions similar to this experiment, developed by Moreira et al. (2014), five maize cultivars (ATL 200, Bona-Verde, AL Branco maize, Itapuã 900 hybrid maize and Sweet maize Havaí) were evaluated for baby corn production and presented PLH mean values ranging from 130 to $174 \mathrm{~cm}$. As the baby corn is usually produced at high population densities, preference should be given to smaller cultivars (Almeida et al., 2005). In the case of the present study, only one cultivar, popcorn UENF-14, was used, with the aim of evaluating the characteristics of maize seedlings use. According to Cruz et al. (2002), the popcorn, because of its short stature and relatively smaller ears, presents an excellent expectation for good results for baby corn production. Thus, the cultivar UENF-14 demonstrated to have a compatible height for easier harvest.

Regarding the stem diameter (PSD), seedlings transplanted at 10 DAS presented PSD $4.9 \mathrm{~mm}$ larger than seedlings trans-planted at 20 DAS. However, PSD of maize plants obtained from direct sowing in field and seedlings transplanted at 30 DAS did not differ significantly $(\mathrm{P}<0.05)$ when compared to the $10 \mathrm{DAS}$ and $20 \mathrm{DAS}$ seedlings (Table 1).
Seedlings transplanted at 10 DAS presented low PLH and high PSD (Table 1). As described by Moreira et al. (2014), short stature and larger stem diameter

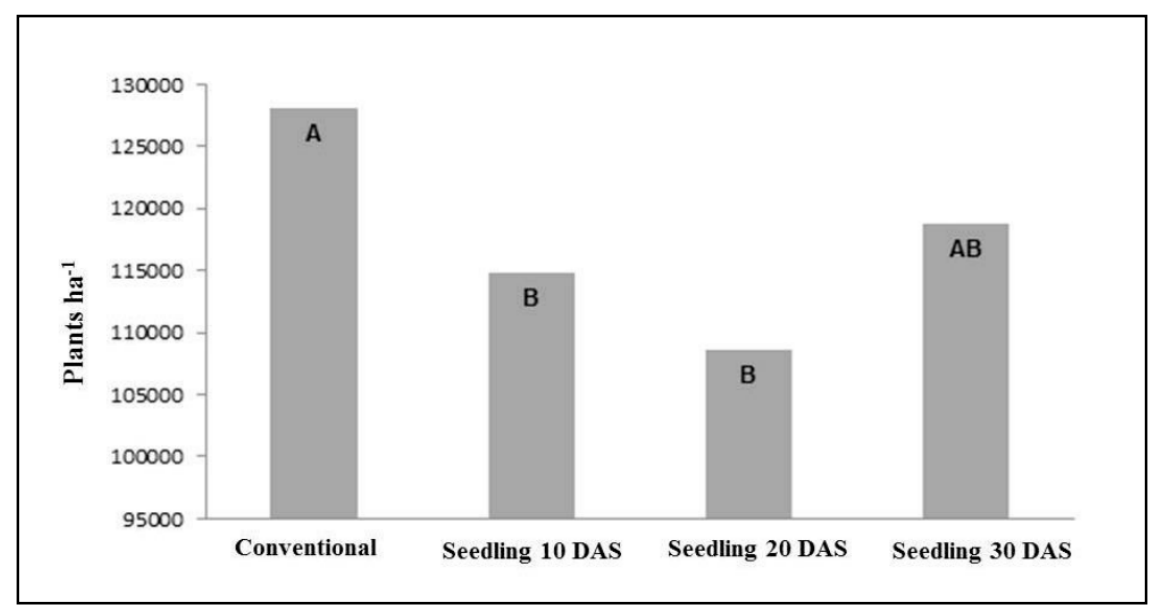

Figure 2. Final stand of maize plants (STA) per hectare of cultivar UENF 14 after direct sowing in field (conventional) or seedlings transplanted in field at diferent stages, for baby corn production, in organic system. DAS = days after sowing; Means followed by the same letters do not differ by Tukey test, at a 5\% probability level. Alegre/Campos dos Goytacazes, IFES/UENF, 2017.
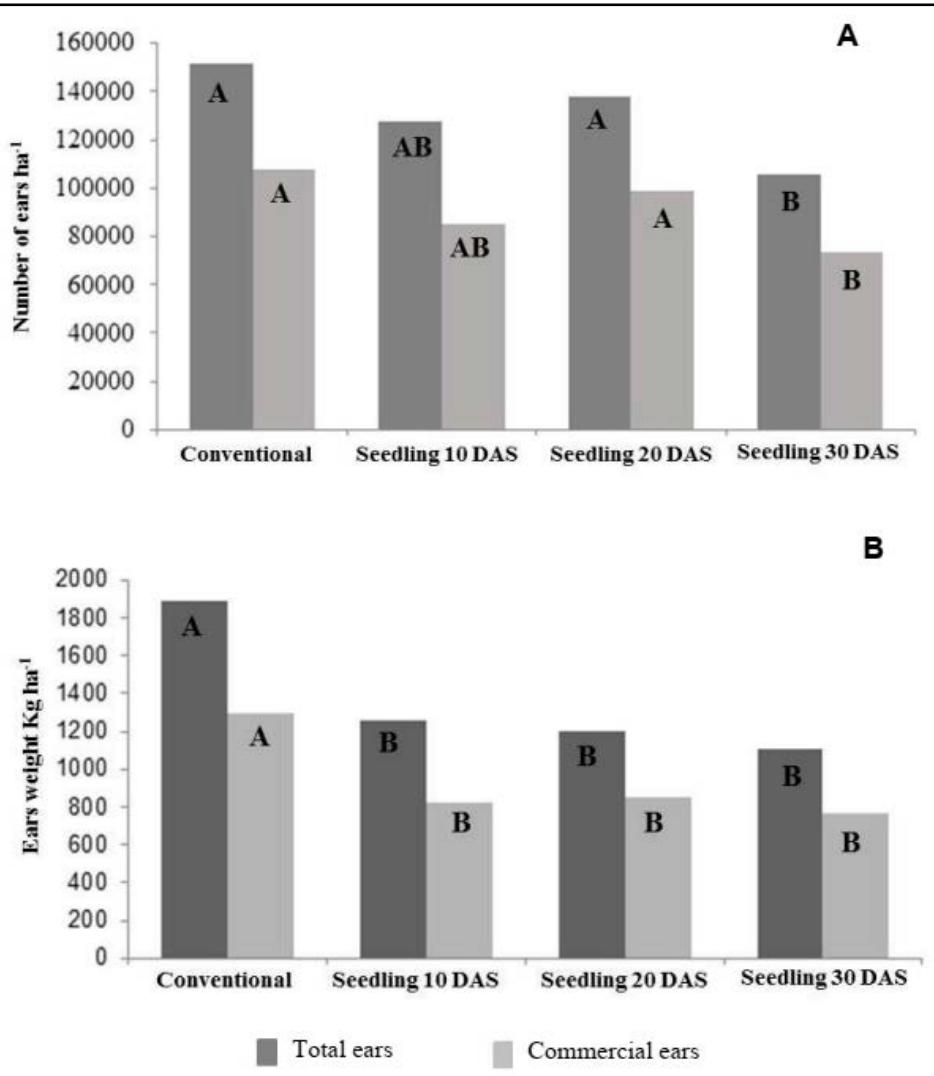

Figure 3. Number of total ears (NTE) and number of commercial ears (NCE) (A); Total ears weight (WTE) and commercial ears weight (WCE) (B) per hectare of the maize 'UENF 14' from direct sowing in field (conventional) or seedlings transplanted in field with diferents days after sowing (DAS) for baby corn production in organic system. Means of total and commercial ears followed by the same letters do not differ by Tukey test, at a 5\% probability level. Alegre/Campos dos Goytacazes, IFES/UENF, 2017. 
a good relationship between these two characteristics is important for baby corn production, since the population density of plants is high. Thus, Cruz et al. (2002) commented that the good quality of the stem, besides being considered a resistance of the plants to bedding and breaking, avoids greater losses during the harvest.

Plants sown direct in field and obtained from seedlings transplanted at 30 DAS presented the largest stands (Figure 2). On average, the stand of maize plants from direct sowing in field presented 16,365 more plants $\mathrm{ha}^{-1}$ than seedlings transplanted at 10 and 20 DAS (Figure 2). On the other hand, STA of 30 DAS seedlings did not differ from plants sown direct in field (conventional) and seedlings of 10 and 20 DAS (Figure 2).

The seedlings transplanted at 10 and 20 DAS had higher mortality in relation to maize plants from direct sowing in field (Figure 2). This fact may have occurred due to the high temperatures during the permanence of the plants in field. Visually in field, it was noticed in the first days after the transplanting, that the seedlings transplanted at 10 and 20 DAS were more wilted than the other plants. Indeed, transpiration was greater than water uptake by maize plants from 10 and 20 DAS seedlings in the first few days after transplanting, which negatively affected the seedlings, with a consequent decrease in the final stand. On the other hand, seedlings transplanted at $30 \mathrm{DAS}$ presented higher plant survival, not differing $(\mathrm{P}<0.05)$ from maize plants directly sown in field (Figure 2). This may have occurred because possibly the root system of seedlings transplanted at 30 DAS was larger than seedlings transplanted at 10 and 20 DAS, which helped them to withstand the negative effects of high temperatures occurring in the month of transplanting. Unfortunately, the length of the seedling roots was not determined in this experiment.

As described by Bastiani et al. (2012), the maize population for baby corn production can be up to 225,000 plants $\mathrm{ha}^{-1}$. Thus, for future researches, it is interesting to evaluate larger populations in planting of maize seedlings for baby corn, in order to guarantee adequate final stand, knowing that a great mortality of plants may occur (Figure 2).

Rezende et al. (2010) described that the planting of good quality watermelon seedlings influences the success of the crop implantation, providing, among other factors, control of the plant stand, which can be difficult with the seeding at the definitive site. On the other hand, Silva et al. (2011), evaluating beet seedlings, verified that at the end of the crop cycle, the transplanted seedlings ages 20 and 30 DAS presented growth and yield similar to those of (conventional) sowing, concluding that it is unnecessary to use seedlings, therefore, the cost of production increases. However, these authors did not quantify this cost over a period of one year in order to assess whether seedling production would increase the number of crop cycles in field, resulting in higher annual yield. According to Belfort \& Gomes (2014),

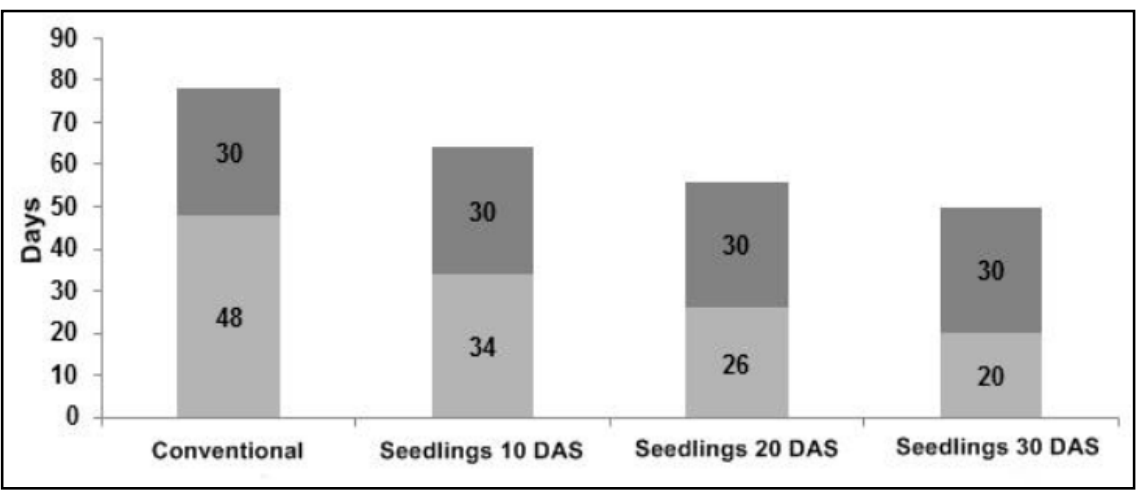

Figure 4. Number of days of the first ear emission until the end of conventional harvesting (direct sowing in field) and transplanting of seedlings of different ages of maize 'UENF 14' after transplanting in field for production of baby corn in organic system. DAS = Days after sowing. Alegre/Campos dos Goytacazes, IFES/UENF, 2017. the failure of many farmers has been attributed to the lack of observation of the appropriate time for transplantation.

Direct sowing and using seedlings transplanted 20 and 10 DAS presented the highest numbers of total and commercial ears per hectare (NTE and NCE) (Figure 3A). Plants from direct sowing and that of seedlings transplanted at 20 DAS showed, on average, 39,021 NTE and 29,603 NCE more than plants from seedlings transplanted at 30 DAS (Figure 3A). On the other hand, seedlings transplanted at 30 DAS did not differ statistically from seedlings transplanted at 10 DAS (Figure 3A).

It is widely known that the reduction of the stand of maize plants results in minor productivity, because the maize has a low capacity to increase production per plant when the stand is reduced. On the other hand, it is interesting to note that the smaller stand of the crops transplanted from 10 and mainly 20 DAS seedlings (Figure 2) did not significantly affect productivity in terms of number of ears, however, plants from seedlings transplanted 10 DAS presented a number of ears that did not differ from the lowest value presented by the 30 DAS seedlings (Figure 3A).

On the other hand, cultivation from seedlings transplanted at 30 DAS, although maintaining a stand that did not differ from conventional direct sowing (Figure 2), provided a number of ears smaller than direct sowing (Figure 3A). Ritchie et al. (2003) emphasize that all the female inflorescences (potential ears) that the maize plant will eventually produce, have its formation in the V3 stage. This can justify the fact that the seedlings transplanted at 30 DAS had lesser number of ears (Figure 3A), because the seedlings were already with three leaves (V3) when transplanted (Figure 1). Possibly, the reduced space for root growth in the container may have adversely affected the development of the plants and, consequently, decreased appearance of the ears. Thus, what limited the development in the period between V2 and V3 of the seedlings transplanted at 30 DAS possibly was the low solar radiation (due to shading) and reduced space for root growth, with 
consequent nutrient deficiency.

It is worth mentioning that, for baby corn, this work is a pioneer and confirms other authors who evaluated the effect of the age of the seedlings on the production of other vegetables. Thus, Piovesan \& Cardoso (2009) comment the influence of the age of the seedlings on production and/or quality on tomato, cucumber, squash and other fruits and vegetable crops.

Direct sowing in field provided superior yields to crops in which transplanted seedlings were used. Thus, crop yield from maize seedlings resulted in a mean decrease of 704 $\mathrm{kg} \mathrm{ha}^{-1}$ of total ears (WTE) and 485 $\mathrm{kg} \mathrm{ha}^{-1}$ of commercial ears (WCE), which was equivalent to a decrease of approximately $37 \%$ in productivity (Figure 3B).

For the baby corn producer, the WCE is the most important, since the product is sold by weight, consequently, the greater the weight of commercial ears per hectare, the greater the producer's profit.

The lower productivity of baby corn from seedlings V1, V2 and V3 with 10 , 20 and 30 DAS, respectively (Figure $3 \mathrm{~B}$ ), is possibly related to the reduction in the final stand for seedlings with 10 and 20 DAS (Figure 2) or reduction of NTE and NCE for seedlings with 30 DAS (Figure 3A).

Santos et al. (2014) reported in their work about maize for baby corn production, that WCE varies, and is often influenced by the stand (STA). In their work, the low population of plants used influenced in a negative way the weight of the ears per area.

Machado et al. (2015), evaluating the transplanting of industrial tomato seedlings, concluded that seedlings that went to the field with higher DAS (days after sowing) presented lower weight of commercial fruits. The authors concluded that, due to deformation in the roots in the container used to produce the seedlings, the plants could not absorb the nutrients adequately, making the weight of the fruits inferior.

Corrêa et al. (2014) observed values of lower commercial ears weight, when compared to the experiment described here (Figure 3B), and those authors obtained a variation of productivity between 797 and $520 \mathrm{~kg} \mathrm{ha}^{-1}$, and in this work with seedlings, the variation of treatments was between 1,297 and $771 \mathrm{~kg} \mathrm{ha}^{-1}$ (Figure 3B).

Moreira et al. (2014) also obtained inferior productivity. The commercial baby corn productivity varied from 464 to $897 \mathrm{~kg} \mathrm{ha}^{-1}$. Although the work of the cited authors was about different cultivars, the work with seedlings was superior, because the plant stand of the works of Moreira et al. (2014) and Corrêa et al. (2014) were higher than that used with maize seedlings in this experiment.

Rangel et al. (2011) reported that the cultivar UENF 14 yields up to two ears per plant when used for grain production. This prolificacy is important for baby corn, because usually the plants produce a greater number of ears due to the removal of the young ears, before the pollination, inducing to the development of new ears.

Tivelli et al. (2011) reported that transplanting in general has the disadvantage of seedling stress, which can cause death or loss of commercial fruit quality, and the intensity of these effects is related to the age of the seedlings and the method of seedlings preparation.

Small urban and peri-urban organic producers tend to prefer to grow plants that increase their profits, thus, the baby corn, because it is easy to cultivate and because it reaches a high market price, has had a great acceptance among this type of farmers. However, the difficulty is still in the small size of the area and the obtaining of the product year-round.

The use of maize seedlings can advance the maize crop in up to 28 days. However, the $37 \%$ reduction in productivity (Figure $3 \mathrm{~B}$ ) makes this method non-viable. In order for this reduction in the period of land use to become interesting, we must investigate other factors that result in increased productivity of the crop from seedlings, at least at levels similar to those obtained by baby corn in direct sowing.

Crops from maize seedlings transplanted on 10, 20 and 30 DAS, V1,
$\mathrm{V} 2$ and V3 respectively, presented in field anticipation of 14, 22 and 28 days for harvest, compared to direct sowing in field (conventional cultivation), respectively (Figure 4). As the period between the beginning and the end of the harvest was 30 days for all treatments, the reduction in field permanence for the seedlings was due to the reduction in the land use period of vegetative stage (Figure 4).

The production of seedlings for the cultivation of vegetables is of usual practice and of great benefit. Madeira et al. (2016) described that several good characteristics are obtained when seedlings are used, among them, the uniformity of the crop, increase of the commercial productivity and fewer days on field until harvests.

Thus, we concluded that the cultivations of 10,20 and 30 DAS of V1, $\mathrm{V} 2$ and V3 maize seedlings presented 14, 22 and 28 days of reduction in field occupation, respectively, in comparison to direct sowing in field (conventional cultivation). However, baby corn from direct sowing made yield 37\% higher than those in which seedlings were used.

In view of this result, it is necessary to carry out new studies on maize seedlings, mainly with seedlings of different ages, container sizes, seedling fertilization, transplanting in different year seasons. Thus, seedlings in the initial vegetative stage certainly do not have good resistance to transplanting. It is known that maize has different growth according to the climate, being affected mainly by the temperature, solar radiation and water availability.

\section{REFERENCES}

ALMEIDA, IPC; SILVA, PSL; NEGREIROS, MZ; BARBOSA, Z. 2005. Baby corn, green ear and grain yield of cultivars. Horticultura Brasileira 23: 960-964.

ARAÚJO, VAS; EKLUND, CRB; COELHO, FC; CUNHA, RCV; LOMBARDI, CT; AGUIAR, RS. 2010. Teor de proteína bruta e produtividade da forragem de milho utilizando resíduos da cultura de minimilho em sistema de plantio direto. Revista Brasileira de Milho e Sorgo 9: 266-276.

BASTIANI, MLR; COELHO, FC; FREITAS, SP; OLIVEIRA, ACS. 2012. Minimilho (Zea mays L.): nitrogênio, fósforo e manejo afetando sua produtividade e a ocorrência de plantas 
daninhas. Vértices 14: 189-20.

BELFORT, CC; GOMES, MSFD. 2014. Avaliação da idade de transplantio para mudas de melancia. Horticultura Brasileira 18: 468-469.

CARMELLO, QAC. 1995. Nutrição e adubação de mudas hortícolas. In: MINAMI, K (ed). Produção de mudas de alta qualidade em horticultura. São Paulo: TA QUEIROZ. p. 33-37.

CORRÊA, AL; ABBOUD, ACS; GUERRA, JGM; AGUIAR, LA; RIBEIRO, RL. 2014. Adubação verde com crotalária consorciada ao minimilho antecedendo a couve-folha sob manejo orgânico. Revista Ceres 61: 956-963.

CRUZ, CD. 2013. GENES. A software package for analysis in experimental statistics and quantitative genetics. Acta Scientiarum Agronomy 35: 271-276.

CRUZ, JC; ALVARENGA, RC; NOVOTNY, EH; PEREIRA, FIA; SANTANA, DP; PEREIRA, FTF; HERNANI, LC. 2002. Cultivo do milho. Sistema plantio direto. Sete Lagoas: Ministério da Agricultura, Pecuária e Abastecimento. Comunicado Técnico. 7p.

EMBRAPA MILHO E SORGO. 2008. Milhos especiais garantem renda extra. https://www.embrapa.br/busca-denoticias/-/noticia/18024867/milhosespeciais-garantem-renda-extra. Available at January 25, 2017. Accessed February 25, 2017.

KARA, B.; BOZKURT, H. 2018. Misırda körpe koçan verim ve bazı özelliklerine hasat zamanlarının etkisi. Kara ve Bozkurt 35: 61-66.

LIMA, ASOD; MELO, AR; OLIVEIRA, LF; TOLENTINO, VR; BRANCO, CSV. 2015. Análises físicas, composição centesimal e nutricional de minimilho (Zea mays, L.) orgânico de diferentes variedades. Revista Verde de Agroecologia e Desenvolvimento Sustentável 10: 49-55.
LIMA, JSS; SILVA, SA; OLIVEIRA, RBDE; CECÍLIO, RA; XAVIER, AC. 2008. Variabilidade temporal da precipitação mensal em Alegre-ES. Revista Ciências Agronômicas 39: $327-332$.

MACHADO, TA; SANTOS, FL; VALENTE, DSM; FERNANDES, HC; CUNHA, JPB. 2015. Transplantio semi-mecanizado de mudas de tomate em função da velocidade de operação. Revista Agroambiente 9: 48-56.

MADEIRA, NR; SILVA, PP; NASCIMENTO, WM. 2016. Cuidados no transplante de mudas. In: NASCIMENTO, WM; PEREIRA, RB (ed). Produção de mudas de hortaliças. 1.ed. Brasília: Embrapa, v. 1., cap. 8, p. 177-194.

MOREIRA, A; SANTOS, MZ; FAVARÃO, SCM. 2014. Características agronômicas de cultivares de milho para produção de minimilho. Revista em Agronegócios e Meio Ambiente 7: 633-643.

NASCIMENTO, WM; PEREIRA, RB. 2016. Produção de mudas de hortaliças. 1. ed. Brasília: Embrapa, 308p.

PEREIRA FILHO, IA; CRUZ, JC. 2001. Manejo cultural do minimilho. In: Empresa Brasileira de Pesquisa Agropecuária (Circular Técnica, 7), Sete Lagoas. 4p.

PEREIRA JÚNIOR, EB; HAFLE, OM; OLIVEIRA, FT; OLIVEIRA, FHT; GOMES, EM. 2012. Produção e qualidade de milhoverde com diferentes fontes e doses de adubos orgânicos. Revista Verde de Agroecologia e Desenvolvimento Sustentável 7: 277-282.

PIOVESAN, MF; CARDOSO, AII. 2009. Produção de abóbora em função da idade das mudas e tipo de bandeja. Bragantia 68 : 651-656.

RANGEL, RM; AMARAL JÚNIOR, ATDO; GONÇALVES, LS; FREITAS JÚNIOR, SP; CANDIDO, LS. 2011. Análise biométrica de ganhos por seleção em população de milho-pipoca de quinto ciclo de seleção recorrente. Revista Ciência Agronômica 42:
473-481.

REZENDE, GM; COSTA, ND; DIAS, RCS. 2010. Sistema de produção de melancia: Plantio. http://sistemasdeproducao.cnptia. embrapa.br/FontesHTML/Melancia/ Sistema ProducaoMelancia/plantio.htm. Accessed December 12, 2016.

RITCHIE, SW; HANWAY, JJ; BENSON, GO. 2003. Como a planta de milho se desenvolve. Arquivo do Agrônomo Potafos, 103: 1-20.

SALATA, AC; HIGUTI, ARO; GODOY, AR; MAGRO, FO; CARDOSO, AII. 2011. Produção de abobrinha em função da idade das mudas. Ciência e Agrotecnologia 35: 511-515.

SANTOS, RF; INOUE, TT; SCAPIM, CA; CLOVIS, LR; MORTELE, LM; SARAIVA, CS. 2014. Produtividade do minimilho em função das adubações nitrogenada e potássica. Revista Ceres 61: 121-129.

SILVA, DMN; TEODORO, RB; OLIVEIRA, FL; QUARESMA, MAL; FÁVERO, C. 2011. Idade de transplantio e poda de raízes nuas de mudas de beterraba sob manejo orgânico. Revista Agrária 82: 147-154.

THAKUR, DR; PRAKASH, OM; KHARWARA, PCE; BHALA, SK. 1998. Effect of nitrogen and plant spacing on yield, nitrogen uptake and economics in baby corn (Zea mays L.). Indian Journal of Agronomy 43: 668-71.

TIVELLI, SW; FACTOR, TL; TERAMOTO, JRS; FABRI, EG; MORAES, ARA; TRANI, PE; MAY, A. 2011. Beterraba: do plantio a comercialização. Campinas: Instituto Agronômico 45p. (Série Tecnologia APTA. Boletim Técnico IAC, 210).

YADAVA, RS; SINGHB, V; PALB, S; MEENAA, SK; MEENAA, VS; SARMA, BK; SINGH, HB; RAKSHITA, A. 2018. Seed bio-priming of baby corn emerged as a viable strategy for reducing mineral fertilizer use and increasing productivity. Scientia Horticulturae 241: 93-99. 